\title{
METAPHYSICAL POEMS
}

GIL. MEDEIROS SAUDADE

\author{
I \\ O LUX BEATA
}

The Triune Light, encompass of all, Whose

Function is to $B E$, eternal, self-aflame,

Wanting nothing, yet brightens Nothing's gloom

With Pearls most pure, our heart and mind's repose.

Thus Good abounds, Love's bounty to disclose,

In myriad harmonic forms - of mirrored fame,

For none but He, our Maker, deserves the Name

Ineffable from Whom all idiom grows.

God, our Father, Thy Grace begets the sphere

Where Reason's thread through cosmic cloth is spun, And Spirit-guided spindles docile veer

To mold the carnal archtypes of the One,

Till roseate Limbo's noblest chanticleer

Crows Creation gowned to greet Thy Sun!

II

A SONG INSANE

Song insane! Flutter of faltering flight!

Satan-ravished the Garden's pristine Rose!

Agape weeps. Archangels plummet bright;

On them perpetual Heaven's portals close!

Michael, Heaven's Constable, salutes

With armored sword His Worship, Annointed Mind, 
Who broods, for toppled oaks with bleeding roots Presage the fall of His adopted kind.

The plot appalls the Word's communing realm:

Who IS must DIE! Let Mercy make amends

Ere Sin all final judgments overwhelm!

Such sorrow the tragic muse transcends.

What pity gracious choirs outpour can heal

The ontic wound the Sacred Scripts reveal?

III

TE DEUM

We spell God in texts of the ontic loom!

What poet could with pallid symbols aspire

To gloss these lyrics of Time's emergent choir,

This cosmic beat of shuttled metronome?

Mute elements we sound, transfigure and transform,

True-unisoned with Being's Tri-chord Lyre,

To crystal-jell Creation's conscient spire,

Midst flesh and folly hopeful wand of wisdom.

Whom shall we praise for garlands of hybrid roses, Harmonic strains of pigment, stone and rod, Incarnate reasons a poet's heart discloses?

Light of labyrinthine ways we trod,

Diapason that each our song composes,

Whom shall we praise but Thee, O Living God?

\section{IV}

\section{CONFITEOR}

I dozed, who vigil kept with Pauline sword, And Tempter, with seasoned rapier, roused the Cain Anesthetized, locked in my soul, insone.

"To kill, he whispered", is act supreme of god!

Nobler by far to strip the fruit than crave Each garden flower, full-blown, festive-gowned, Scented sweet with balm to bless the wound!"

The deed was done. O MISER, Jester s slave! I wrapped the spoils, Sin's cancrous-cultured pearls, In gilded, soft, Grace-insulated cloth:

Reason shuttling in cosmogonic swirls The spindled excrement of Serpent's froth! What price these trophies when the Scroll unfurls IN DIE TREMENDO of God's avenging Wrath? 